\title{
The Effectiveness of Application Discovery Learning Model of Multiple Intelligences-Based on Science Critical Thinking Skills in Grade V Elementary School Students in Buton Regency
}

\author{
Erman Suwardi ${ }^{1}$, Ani Rusilowati ${ }^{2}$, Sri Wardani ${ }^{3}$ \\ ${ }^{1}$ Master Program, Student of Primary Education, ${ }^{2,3}$ Master Program, of Primary Education, \\ Universitas Negeri Semarang, Semarang City, Indonesia. \\ Corresponding Author: Erman Suwardi
}

DOI: https://doi.org/10.52403/ijrr.20220236

\begin{abstract}
This research was conducted based on the results of observations and interviews on the low critical thinking skills of students in elementary school cluster 9 Pasawajo subdistrict which had an impact on student learning outcomes. The purpose of this study was to analyze the differences in the effectiveness of the multiple intelligences-based discovery learning model with the discovery learning model on the science critical thinking skills of fifth grade elementary school students. This type of research uses quantitative methods with a quasi experimental design that applies experimental and control classes. Data collection techniques were carried out by observing, giving tests, student response questionnaires and documentation. The samples of this study were the fifth grade students of SDN 113 Buton as the experimental class and the fifth grade students of SDN 91 Buton as the control class. The research instrument was conducted by first analyzing the results of the test trials including the validity of the reliability, the level of difficulty, and the differentiating power of the questions. The data analysis technique used was normality test, homogeneity test, completeness test and hypothesis testing using independent sample t-test after which the gain test is carried out. The results of the study can be concluded that there was a significant difference in the effectiveness of students' critical thinking skills between the multiple intelligences-based discovery learning model
\end{abstract}

and the discovery learning model. The results of the average difference test using the independent sample t-test obtained a sig value. (2-tailed) the experimental and control classes were $0.000<0.05$, so Reject H0 which means that there are differences in critical thinking skills. The results of classical completeness using the $\mathrm{Z}$ test obtained that the experimental class achieved more than $75 \%$ completeness and the control class was less than $75 \%$. The data results from the experimental class gain test obtained a gain value of 0.56 higher than the control class with a value of 0.42 even though both classes were in the medium gain category, but the experimental class increased higher than the control class.

Keywords: discovery learning Model, multiple intelligences, critical thinking ability, learning science.

\section{INTRODUCTION}

Education has an important role for every individual in character building to become virtuous, intelligent, creative, independent, responsible human beings and become citizens who can advance and develop the Indonesian nation. Education in Indonesia needs to be improved and changed to all aspects that affect the success of education including curriculum, educators, students, learning models, and infrastructure in the learning process. A series of interactive, fun and student- 
centered learning activities to create creativity and independence.

Students' independence in learning will be meaningful if students are active in finding their own knowledge. Learning activities carried out with discovery will give good and meaningful results. In addition, student learning activities must have an attitude of confidence in their abilities (Rosarina et al., 2016). According to Bandura's learning theory, a person who has a high self-confidence tends to be successful with his abilities. A person's attitude of feeling confident can achieve student success in the science learning process (Ghasya \& Suryanti, 2014).

The learning process of Natural Sciences (IPA) is a subject related to natural events or phenomena. In elementary school, science lessons are used as a tool to study oneself, the natural environment and apply it in daily life. Science subjects aim to make students have good knowledge, skills, and attitudes to adapt to the development of science. Science provides many opportunities for students to find out new concepts by using their knowledge and reason (Hutomo et al., 2016)

Aspects that are developed to reach the objectives of learning science can be achieved, namely the students' critical thinking skills. The ability to think critically is very important, because it is one of the scientific attitudes that students must have in the science learning process. If students lack critical thinking skills, students will find it difficult to solve problems or problems in science learning. Azizah et al., (2018) suggest that critical thinking skills are students' cognitive processes in analyzing problems, distinguishing problems carefully and thoroughly, as well as identifying and reviewing information to plan problem solving strategies at hand.

Critical thinking skills can be developed in school learning. Learning is said to be good if it is carried out not only conveying material, but can stimulate students' critical thinking skills. As stated by Prihanti, (2015) that critical thinking skills in the learning process can make learning retention higher, learners are more active, the knowledge gained is wider, able to sort out the right information or learning resources.

The learning process in the classroom is generally only directed at the ability to memorize information. Students are only forced to remember and hoard various information without being required to understand the information obtained to combine it with situations in everyday life (Mareti \& Hadiyanti, 2021). The low critical thinking ability of students will have an impact on the lack of students in understanding the learning material and is a problem that often arises in science learning. Students' critical thinking skills are very important in the learning process, not only memorizing material that students do not necessarily understand, it can also affect student learning outcomes if their thinking skills are low.

Students' critical thinking ability is low, because learning focuses more on students to memorize, without paying attention to the development of thinking skills (Surtriyanti et al., 2017). Learning that only emphasizes memorization will not be able to optimize students' critical thinking skills. Meanwhile, (Wijayanti et al., 2015) also stated that students' critical thinking skills were influenced by several factors, namely (1) disturbed physical conditions so students could not concentrate in answering questions; (2) lack of student motivation in learning activities; (3) The concept of critical thinking skills is still poorly understood by teachers; (4) Intellectual development; and (5) the interaction of teachers with students so that the learning atmosphere is less comfortable.

The above factors make students have difficulty when learning and less able to conclude the material. Therefore, critical thinking skills must be developed so that learning objectives are achieved and the school environment needs to be conditioned to develop students' critical thinking skills, because critical thinking skills cannot arise 
by themselves, but there must be teacher efforts to provide meaningful experiences in the learning process.

Based on the results of observations and interviews that researchers conducted with several fifth grade teachers in cluster 9 elementary schools in Pasarwajo subdistrict, it showed that students' critical thinking skills were still low. This is marked by: first, at least students who are active and most tend to be passive only pay attention to the teacher so that the ability of students to ask questions and express income in solving problems is less than optimal. Second, students are less involved or actively involved in understanding the concepts that exist in science learning so that the impact is unable to develop aspects of students' critical thinking skills. Third, students find it very difficult to relate some subject matter to everyday life and relate it to predetermined learning outcomes. Fourth, learning activities are carried out by following the teacher's learning style, not from the learning style of each student, this is because there is no processing of multiple intelligences in students in learning. Fifth, the class teacher still uses the lecture method on the grounds of having difficulty in designing learning models and strategies, so that the learning outcomes in science subjects do not reach the minimum completeness criteria (KKM).

Table 1 Completeness of Final Grade Science Semester Class V Semester I

\begin{tabular}{|c|c|c|c|c|}
\hline No & \multicolumn{4}{|c|}{ Academic Year 2020/2021 } \\
\hline & School Name & $\mathbf{N}$ & $\begin{array}{ll}\text { ¿Student } & \text { fulfill } \\
\text { KKM } & \\
\end{array}$ & $(\%)$ \\
\hline 1 & SD Negeri 91 Buton & 26 & 13 & 50 \\
\hline 2 & $\begin{array}{l}\text { SD Negeri } 113 \\
\text { Buton }\end{array}$ & 28 & 12 & 43 \\
\hline
\end{tabular}

The low learning outcomes in science learning should become a reflection for teachers and education in Indonesia in general, especially in elementary schools to create active and innovative learning that fights in the development of students' multiple intelligences. Therefore, education requires a learning theory that is able to accommodate students' multiple intelligences in learning, so that learning becomes easier to understand. One theory that can be applied to solve these problems is the theory of Multiple Intelligences.

The theory of multiple intelligences believes that every individual has intelligence according to the dominant type of intelligence that is possessed from birth or can be developed as a result of education in culture (Fathani, 2016; Gunduz \& Unal, 2016 ). In the learning process, of course, it can be done and developed by looking at the potential and multiple intelligences possessed by students. Basically, each student has different intelligences, some tend to have one intelligence, but some have two or more dominant intelligences. The various intelligences possessed by students are the color and diversity that is formed in the students themselves. Teachers must be able to recognize and understand the intelligence abilities of students so that students feel motivated in learning when teachers appreciate the intelligence they have (Pitriani et al., 2020).

In realizing students' critical thinking skills, it can be done with various efforts, one of which is the use of learning styles that are in accordance with the dominant multiple intelligences possessed by students and the learning model used by teachers. Critical students will greatly impact in overcoming and answering all problems in learning, especially learning science. Training students in using multiple intelligences will make students active, remember and understand their critical thinking skills so as to help them in solving and solving problems in science learning that are associated with everyday life (Mujib \& Mardiyah, 2017). This is what makes researchers interested in seeing students' critical thinking skills based on the multiple intelligences students have. The intelligence that students have in following the steps of the learning process is part of the development of critical thinking processes through awareness that is understood by students so that it will indirectly result in students' understanding of concepts. 
Multiple intelligences theory from Howard Gardner, suggests that every individual has nine types of intelligence in him, consisting of (1) verbal-linguistic intelligence; (2) logical-mathematical intelligence; (3) visual-spatial intelligence; (4) rhythmic-musical intelligence; (5) interpersonal intelligence; (6) intrapersonal intelligence; (7) natural intelligence; (8) physical-kinesthetic intelligence and (9) existential-spiritual intelligence. Each individual has the nine intelligences, there are only a few dominant intelligence tendencies (Wijayanti \& Widiyatmoko, 2015). Learning that is adapted to the type of student intelligence allows students to play an active role in maximizing their intelligence. By maximizing this intelligence, students will easily understand concepts in science learning and stimulate their critical thinking skills properly and logically. However, this needs to be applied through a learning process with scientific steps to achieve optimal results.

One of the efforts that can be made to support the learning process based on these scientific steps is to implement innovative learning models such as the Discovery Learning model. Discovery learning is a learning model to encourage students to be active by finding their own knowledge to think critically (Kristin \& Rahayu, 2016). One of the characteristics of the discovery learning model according to Hosnan, (2014) is teaching students to be active in exploring and solving problems systematically starting with the stages of stimulation, problem identification, data collection, data processing, verification or proof to draw generalizations or conclusions.

Through the process of discovery learning model stages above, students are able to work and think with scientific steps, actively discover new things and improve critical thinking skills that affect students' conceptual understanding (Aryani \& Wasitohadi, 2020). This Discovery Learning model places students in an environment that is conditioned in the form of an exploratory learning design, where students play an active role in the learning process. The use of discovery learning models is expected to improve the learning process in the classroom. By using the Discovery Learning model, learning will be more fun and students will more easily understand the subject matter while at the same time increasing students' critical thinking skills to be optimal.

The implementation of discovery learning and multiple intelligences-based learning models was chosen to improve problems in science learning in class $\mathrm{V}$ Elementary School Cluster 9 in Pasarwajo District by moving on from several studies about the significant influence on the application of discovery learning and multiple intelligences-based learning models on students' critical thinking skills. in science learning. These studies include: research conducted by Septiana \& Ikhsan, (2017) showed a significant influence before and after the application of multiple intelligences in science learning on students' conceptual understanding; research conducted by Winarti et al., (2019) showed a positive influence on the implementation of the PMK-KM strategy on students' critical thinking skills; Research conducted by Lieung, (2019) shows that the discovery learning model has a significant positive effect on students' critical thinking skills.

Based on the background and previous research, the application of the discovery learning model and multiple intelligences were assumed to have a significant effect on the science critical thinking skills of students in class V SDN in cluster 9, Pasarwajo sub-district, Buton Regency.

\section{MATERIALS \& METHODS}

This study used a quantitative research method with a quasi-experimental research design. This study consisted of an experimental class and a control class, each class was given a pre-test question to determine the students' initial state abilities, then treatment was carried out in the 
Erman Suwardi et.al. The effectiveness of application discovery learning model of multiple intelligences-based on science critical thinking skills in grade V elementary school students in Buton Regency.

experimental class using a discovery learning model based on multiple intelligences and the control class using discovery learning, after receiving the second treatment. The class was given posttest questions aimed at knowing students' critical thinking skills. The population of this research was all fifth-grade elementary school students in cluster 9 Pasarwajo District, Buton Regency for the 2021/2022 academic year. The sampling technique was purposive sampling, where class V SDN 113 Buton as the experimental class and Class V students at SDN 91 Buton as the control class, totalling 53 students.

Data collection is collected by test and non-test. The test was by giving a description of 10 items of critical thinking skills to students and non-test, namely through direct observation both before and during the learning process with student observation sheets, also done by giving student response questionnaires and documentation. The research instrument was carried out by first analysing the results of the test questions by validating the questions and other instruments to the expert validators, after that the results of the test questions were analysed for the level of validity, reliability, differentiating power and the level of difficulty of the questions. The data processing technique was carried out by conducting prerequisite tests, namely normality and homogeneity tests with the Kolmogorov-Smirnov test using the SPSS version 22 programs. The results of the normality test of critical thinking skills in the experimental and control classes can be shown in Table 2 below.

Table 2. Normality Test of Critical Thinking Skills in Experimental and Control Classes.

\begin{tabular}{|c|c|c|c|c|c|c|c|}
\hline \multicolumn{8}{|c|}{ Tests of Normality } \\
\hline & \multirow{2}{*}{ Class } & \multicolumn{3}{|c|}{ Kolmogorov-Smirnov ${ }^{\mathrm{a}}$} & \multicolumn{3}{|c|}{ Shapiro-Wilk } \\
\hline & & Statistic & df & Sig. & Statistic & df & Sig. \\
\hline \multirow{2}{*}{ Pre-test } & SDN 113 Buton & .152 & 27 & .109 & .926 & 27 & .056 \\
\hline & SDN 91 Buton & .151 & 26 & .132 & .933 & 26 & .090 \\
\hline \multirow[t]{2}{*}{ Post-test } & SDN 113 Buton & .162 & 27 & .066 & .933 & 27 & .084 \\
\hline & SDN 91 Buton & .143 & 26 & .185 & .928 & 26 & .070 \\
\hline
\end{tabular}

The data from the homogeneity test of critical thinking skills in the experimental and control classes can be shown in Table 3 below.

Table 3. Test of Homogeneity of Critical Thinking Skills in Experimental and Control Classes.

\begin{tabular}{|l|l|l|l|l|l|}
\hline \multicolumn{2}{|c|}{ Test of Homogeneity of Variance } \\
\hline & & Levene Statistic & df1 & df2 & Sig. \\
\hline Post-test & Based on Mean & .850 & 1 & 51 & .361 \\
\hline Prettest & Based on Mean & .712 & 1 & 51 & .403 \\
\hline
\end{tabular}

\section{RESULT}

The difference in the effectiveness of the multiple intelligences-based discovery learning model with the discovery learning model on science critical thinking skills is based on the following indicators: (1) The average critical thinking ability of students has achieved classical mastery of at least $75 \%$; (2) The average ability of students in terms of critical thinking skills in the discovery learning model based on multiple intelligences is better than the discovery learning model; and (3) The average critical thinking ability of students increased after learning on the discovery learning model based on multiple intelligences.

\section{The average critical thinking ability of students achieves classical completeness}

Classical completeness aims to test whether the proportion of students who reach the KKM, which is 70 , reaches $75 \%$. Classical mastery learning was tested using the one-sided proportion test with the classical mastery criteria of $75 \%$.

$\mathrm{Z}=\frac{\frac{x}{n}-\pi_{0}}{\sqrt{\frac{\pi_{0}\left(1-\pi_{0}\right)}{n}}}$ 
Erman Suwardi et.al. The effectiveness of application discovery learning model of multiple intelligences-based on science critical thinking skills in grade V elementary school students in Buton Regency.

Notes

$\mathrm{Z} \quad$ : proportion test (z count)

$\mathrm{x}$ : the number of participants who have achieved complete learning

$\pi_{0} \quad$ : hypothesized value

$n \quad$ : number of samples

Reject criteria $\mathrm{H}_{0}$ if $\mathrm{Z}_{\text {hitung }} \geq \mathrm{Z}_{0,5-\alpha}$ with $\alpha=5 \%$ or 0,05 where $Z \alpha$ obtained from the standard normal list, for $Z_{\text {count }}<$ $\mathrm{Z}_{0,5-} \quad \alpha$ hypothesis $\quad \mathrm{H}_{0}$ accepted. The summary of the results of the classical completeness test scores can be seen in table 4 below.

Table 4. Summary of Classical Mastery Test Values Critical Thinking Skills

\begin{tabular}{|l|l|l|}
\hline $\mathbf{Z}$ Test & $\mathbf{Z}_{\text {table }}$ & Zcount \\
\hline & 1,703 & 3,246 \\
\hline Experiment Class & 1,705 & $-0,226$ \\
\hline Control Class
\end{tabular}

The results of the data in Table 4 show that in the experimental class the standard normal table list shows the results $\mathrm{Z}_{\text {table }}$ about 1,703 with a significance level used of 0.05 or $5 \%$, because $Z_{\text {count }}>Z_{\text {table }}$ or $3,246>1,703$ then rejected $\mathrm{H}_{0}$ and accepted $\mathrm{H}_{1}$, while the results of the data on the control class list of standard normal tables obtained results $Z_{\text {table }}$ about 0,705 significant score 0,05 or $5 \%$, because $Z_{\text {count }}<Z_{\text {table }}$ or $0,226<1,705$ then rejected $\mathrm{H}_{0}$ and accepted $\mathrm{H}_{1}$, so it was concluded that the proportion of critical thinking skills scores of experimental class students met the minimum completeness criteria (KKM) 70 to reach more than $75 \%$, while in the control class the proportion of students' critical thinking skills scores was less than $75 \%$. The classical test of critical thinking skills can be seen in figure 1 .

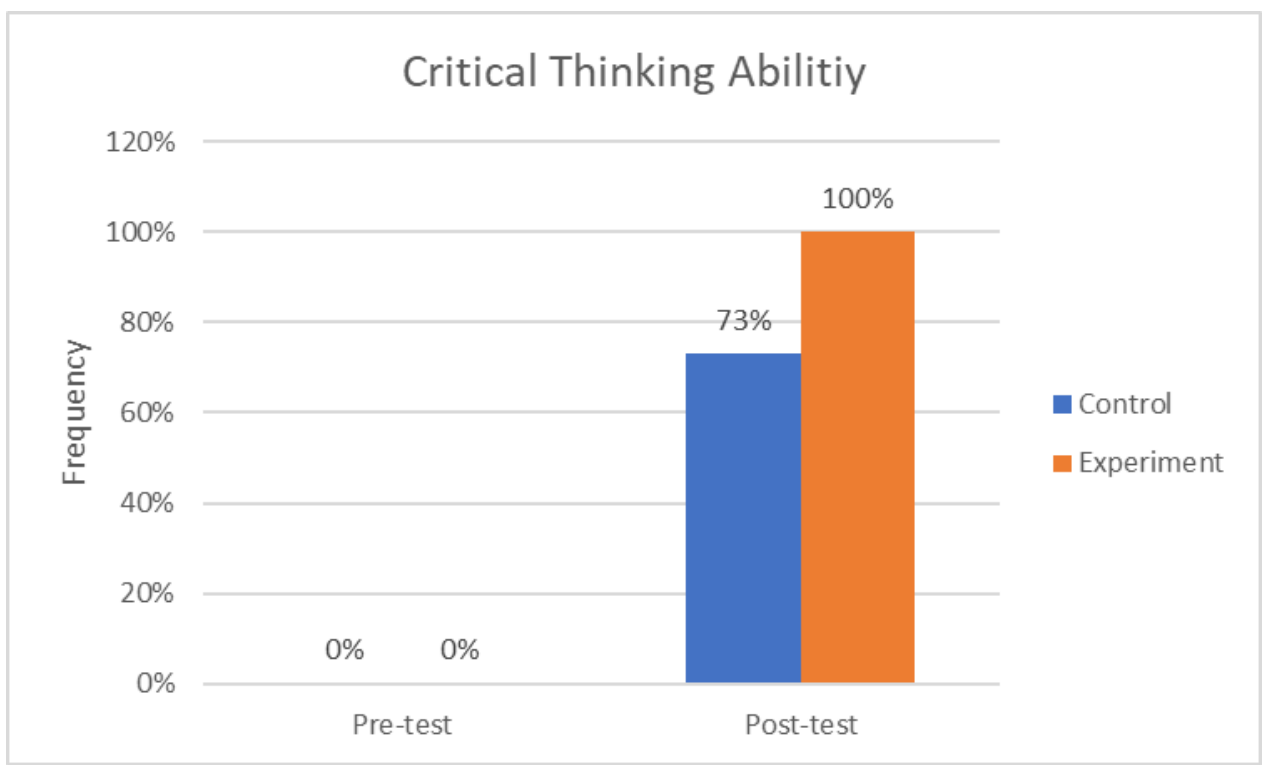

Figure 1. Graph of the Percentage of Classical Tests for Critical Thinking Skills

The average ability of students to think critically in the discovery learning model based on multiple intelligences is better than the discovery learning model

The average difference test was used to determine the average difference between the critical thinking skills of the class using the discovery learning model based on multiple intelligences and those using discovery learning. The comparison test was carried out using the SPSS 23.0 application for windows using the independent sample t-test with sig level. (2-tailed) $<0.05$. The results of the independent sample t-test calculation on students' critical thinking skills can be shown in Table 5 below.

Table 5. Posttest t-test of Critical Thinking Skills

\begin{tabular}{|l|c|l|l|l|}
\hline Sig.(2-tailed) & $\boldsymbol{\alpha}$ & \multicolumn{2}{|l|}{ Mean } & Remark \\
\cline { 3 - 4 } & & Experiment & Control & \\
\hline 0,000 & 0,05 & 83.56 & 73.15 & There were differences in students' critical thinking skills \\
\hline
\end{tabular}


The results of the data in Table 5 shown that the post-test data on critical thinking skills in the experimental and control classes obtained a sig. (2-tailed) value was $0.000<0.05$, then Rejected $\mathrm{H}_{0}$ and accepted $\mathrm{H}_{1}$ which meant that there were differences in critical thinking skills in the same class. taught by the multiple intelligences-based discovery learning model and the class taught by the discovery learning model, because there are differences, then seen in the mean table, in the table it is known that the average value of the experimental class is 83.56 and the control class is 73.15 . The average of the experimental class was more than the average of the control class, it concluded that there was a difference in critical thinking skills between the experimental class and the control class. In order to find out more about the increase in the value of critical thinking skills in the experimental and control classes, it can be shown in Figure 2 below.

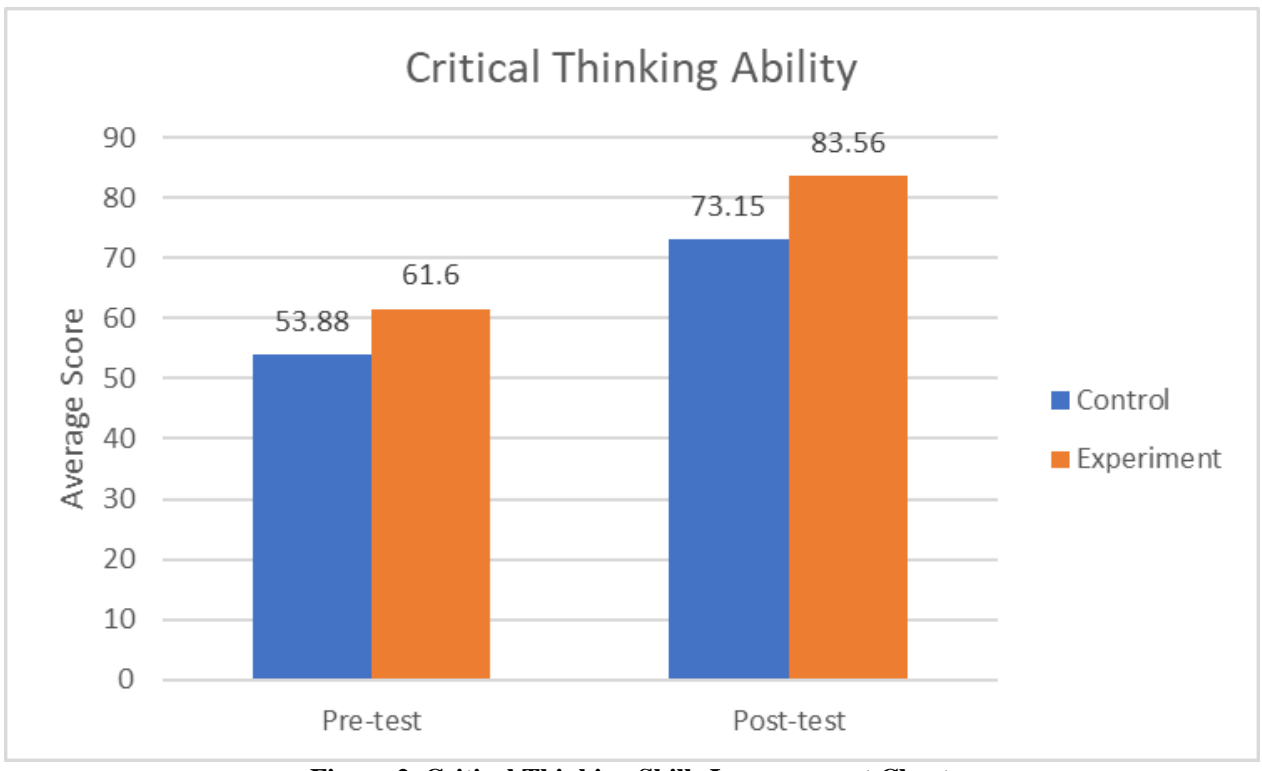

Figure 2. Critical Thinking Skills Improvement Chart

The average critical thinking ability of students increased after learning the discovery learning model based on multiple intelligences.

The gain test was conducted to determine the difference between the pretest and posttest scores in the experimental class and the control class. The data obtained by the $\mathrm{N}$-Gain experimental class and the control of students' critical thinking skills can be shown in Table 6 below.

Table 6. Calculation Results of N-Gain Critical Thinking Skills

\begin{tabular}{|l|l|l|l|l|}
\hline Class & Pre-test & Post-test & Gain Value & Criteria \\
\hline Experiment & 61,60 & 83,56 & 0,56 & Medium \\
\hline Control & 53,88 & 73,15 & 0,42 & Medium \\
\hline
\end{tabular}

The results of the data in Table 6 can be seen from the comparison of the average gain in the control and experimental classes, in the control class, the average gain is 0.42 in the medium category, while the experimental class has an average gain of 0.56 which is classified in the medium category. This shows that the average gain in critical thinking skills of experimental class students was higher than the control class, even though both are classified in the medium category. The results of the percentage of students who fall into the low, medium, and high classification in control and experiment class can be shown in figure 3 below 
Erman Suwardi et.al. The effectiveness of application discovery learning model of multiple intelligences-based on science critical thinking skills in grade V elementary school students in Buton Regency.

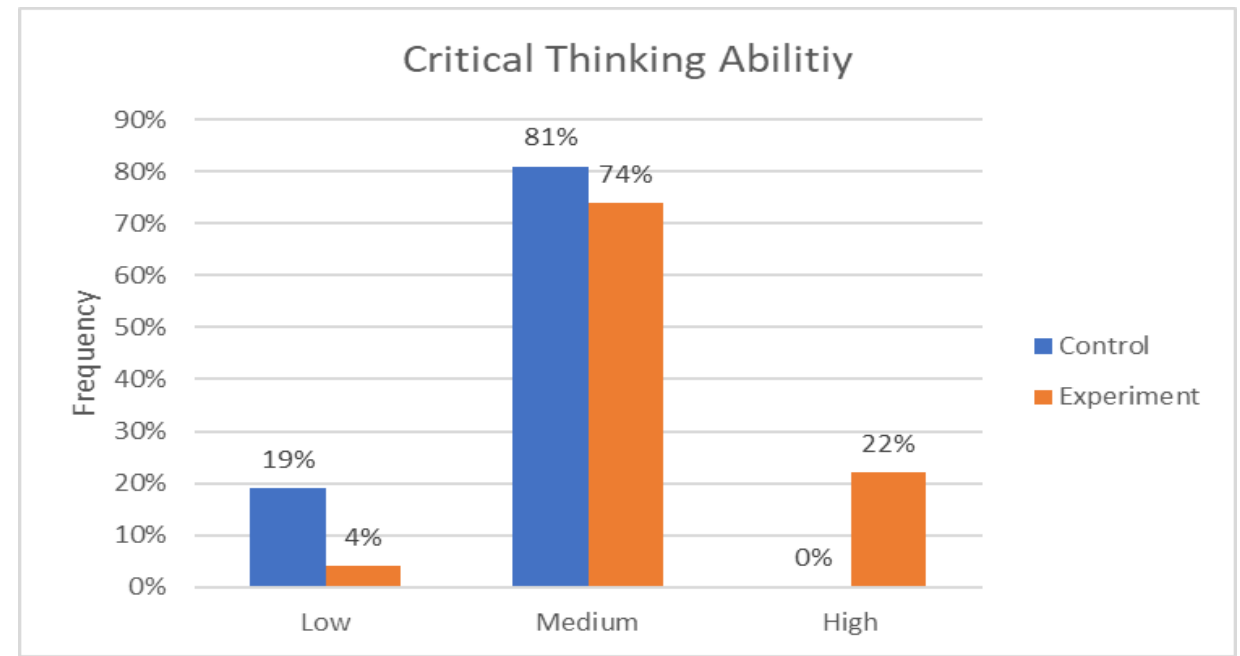

Figure 3. Graph of Critical Thinking Skills Improvement Based on N-Gain Criteria

\section{DISCUSSION}

This study was conducted to analyze students' critical thinking skills before and after discovery learning model of multiple intelligences-based in the experimental class and discovery learning model in the control class, the data analyzed were the pretest and posttest scores in the experimental class and control class.

The results of the initial data analysis from the pretest score data showed that the critical thinking skills of students in the experimental class and control class were both in the category of not meeting learning mastery both individually and classically. The average value of critical thinking skills in the experimental class is 61.60 in the pretest value of critical thinking skills, the lowest is 50 and the highest score is 68 with 27 students, none of the students meet learning mastery, while in the control class the average value is 53,88 in the pretest value of critical thinking skills, the lowest is 45 and the highest score is 60 with a total of 26 students, none of the students experienced mastery learning.

The fact from the results of the pretest data analysis is influenced by learning that only emphasizes students' memorization without stimulating their critical thinking skills so that it has an impact on the lack of students understanding the subject matter, this is in line with the research of Mareti \& Hadiyanti, (2021) which suggests that the learning process in the classroom at generally only directed at the ability to memorize information, students are only forced to remember and hoard various information without being required to understand the information obtained to combine it with situations in life. Therefore, it is important for a teacher to carry out learning by developing students' thinking skills actively so that students can understand a material concept conveyed by the teacher.

After the pre-test was carried out in the experimental class and the control class, learning activities were carried out by giving treatment by implementing the discovery learning model based on multiple intelligences in the experimental class and the discovery learning model in the control class twice with the same material, namely the organs of blood circulation in humans and how to maintain them in the first meeting and the organs of blood circulation in animals and their maintenance at the second meeting. After two lessons, the students then did the post-test of critical thinking skills. The questions given to the experimental class and control class were the same.

The results of the post-test scores showed that the average critical thinking skills of students in the experimental class was 83.56 with the number of students who completed the KKM as many as 27 students, all of them completed individually and achieved a classical completeness score of 
$100 \%$ with the lowest critical thinking skill posttest score of 75 and the highest ie 90 there was an increase in posttest results, while in the control class the average critical thinking skill was 73.15 with the number of students who completed the KKM as many as 19 out of 26 students and 7 students did not meet the KKM completeness with the number of classical completeness was $73 \%$ with a score of The lowest critical thinking skill posttest is 63 and the highest is 80 from the acquisition value, so the control class has not met the classical completeness of $75 \%$. So from these results it can be seen that the improvement of students' critical thinking skills in the experimental class is better than students in the control class.

The difference in increasing the effectiveness of critical thinking skills in the experimental class that implemented the discovery learning model based on multiple intelligences and the control class that applies the discovery learning model is seen from the comparison of the average posttest scores of students' critical thinking skills. The results of the research on the difference in the average posttest score of critical thinking skills between the experimental class and the control class were seen from the analysis on the value of sig.(2-tailed) which showed that the value of sig.(2-tailed) was $0.000<0.05$ then $\mathrm{H}_{0}$ rejected, which means that there are differences in critical thinking skills in the discovery learning model class based on multiple intelligences as the experimental class and the discovery learning model class as the control class.

More results to determine the high of the increase in critical thinking skills that occurred in the experimental class and control class, the researcher also conducted the N-Gain test. The results of the N-gain test showed that the increase in the pre-test to post-test scores in the experimental class gained an average value of 0.56 so that it could be categorized in the medium category, while critical thinking skills in the control class gained an average value of 0.42 in the middle category. medium category, Although the experimental and control classes both experienced an increase in the moderate category, the $\mathrm{N}$-Gain value in the experimental class was higher than the control class. The difference in the $\mathrm{N}$ Gain value shows that the increase in the pretest value to the posttest value that occurs in the experimental class is better than the control class. This increasing difference can also be seen in the results of the percentage of students into low, medium and high categories where in the experimental class obtained $22 \%$ of students for the high category, $74 \%$ for the medium category, and $4 \%$ for the low category. On the other hand, the case with the acquisition of scores in the control class for students in the high category of $0 \%$, medium category students $81 \%$, and students in the low category $19 \%$, from these results it is clear that there are differences in the increase in $\mathrm{N}$-Gain between classes that are taught using discovery learning models based on multiple intelligences and classes that are only taught with the discovery learning model.

The results that occurred in the difference in the effectiveness of the two classes, there were the experimental class and the control class, it is occurred because of the difference in the treatment given. In the experimental class, with the discovery learning model based on multiple intelligences, it puts forward the discovery process that is carried out and explored through the students' multiple intelligences. Students were able to develop their critical thinking skills because it is covered by LKPD which is adjusted to the dominant intelligence possessed by students. In line with research conducted by (Wijayanti \& Widiyatmoko, 2015) said that the development of worksheets made referring to the dominant intelligence of students will make learning more meaningful and enjoyable in developing students' thinking intelligence. This can be seen in the problem identification and data processing phase, students in groups try to formulate a temporary hypothesis on the questions given by the teacher, with the temporary 
hypothesis students collect data and process their findings to be verified with the hypothesis made. The ability of students' logical mathematical and visual spatial intelligence is needed in analyzing the results of data processing, thus spurring students to think critically in proving the findings that would become concepts in their inventions.

In contrast to the control class, students were only treated with a discovery learning model without being facilitated with a learning process adapted to multiple intelligences. Students are not supported by LKPD which is designed according to the dominant intelligence of each student. This can be seen in the learning process, in the data collection, processing and data verification phases, it can be seen that some groups of students experience problems in processing their findings. Some students still have difficulty developing critical thinking skills to analyze their findings logically and the frequency of students asking the teacher to be directed to find their own concepts from the material being taught makes students confused, although some students are still difficult to find their own concepts of the material being studied but some of them others are able to process their findings to be verified with the hypotheses made in the problem identification phase.

Based on the results of the exposure of the difference in the effectiveness of critical thinking skills between the experimental class and the control class, it shows that the average student's critical thinking skills using the discovery learning model based on multiple intelligences are better than the average student using the discovery learning model. This was aligned with research conducted by Maula \& Arief, (2014) looking at how the improvement of critical thinking skills and the implementation of students' multiple intelligences-based learning, from the results of data analysis, student learning outcomes have increased after being taught with multiple intelligences-based learning, meaning multiple-based learning. intelligences give influence to students' critical thinking skills and the implementation of learning goes well. Another study was conducted by Kusumaningtias et al., (2014) from the results of his research that multiple intelligences-based handouts were able to improve students' critical thinking skills. The same thing was also done by Winarti et al., (2019) in their research to measure the effectiveness of multiple intelligences-based problem-solving strategies in improving critical thinking skills, the results of their research show that the PMK-KM strategy was effective in improving students' critical thinking skills.

Learning by implementing students' multiple intelligences was a learning approach that is able to optimize or maximize the intelligence of students properly and efficiently so that students feel valued because of the differences in each intelligence they have. The implementation of the multiple intelligences-based discovery learning model in the experimental class is able to provide new experiences for students who are accustomed to learning with a teacher centered approach, because in the implementation of this model the direction of learning changes to student centered, the teacher's role in learning is only as a facilitator, thus learning is more meaningful for students. students because students feel they learn directly from their experiences, this was strengthen by research conducted by Wardani et al., (2016) which suggests that learning that gives students many opportunities is called meaningful learning which will make it easier for students to remember material and stimulate skills. critical thinking becomes more optimal. The use of discovery learning models based on multiple intelligences was able to increase students' motivation in participating in science learning, making students more familiar with their dominant learning styles, so that students will more easily exploit materials in their environment as 
Erman Suwardi et.al. The effectiveness of application discovery learning model of multiple intelligences-based on science critical thinking skills in grade V elementary school students in Buton Regency.

appropriate learning resources (Wijayanti et al., 2016).

\section{CONCLUSION}

Based on the findings of the data and discussion, it can be concluded that.

1. There are differences in the effectiveness of critical thinking skills in the experimental class and the control class. This proven from the value of sig. (2-tailed) showing the results of the value $0.000<0.05$ proving that there is a difference in the average value of critical thinking ability of the experimental and control classes after being given treatment. In the mean box table it can also be seen that the average critical thinking skill in the experimental class is 83.56 , while in the control class it was 73.15. The results of the increase in effectiveness were also seen from the results of the $\mathrm{N}$-Gain test in the experimental class the average gain value is 0.56 and the average gain value in the control class is 0.42 , although both classes are in the medium category, this shows that the discovery learning model is better at providing effectiveness to students' critical thinking skills than the discovery learning model.

2. Implementation of discovery learning model based on multiple intelligences was a fun learning model for students. Students become motivated in learning because learning is designed according to the dominant intelligence possessed by each student, so that none of the students feel neglected, even students could feel appreciated by facilitating their learning based on their multiple intelligences.

Acknowledgement: None

Conflict of Interest: None

Source of Funding: None

\section{REFERENCES}

1. Aryani, Y. D., \& Wasitohadi, W. (2020). Pengaruh Penerapan Model Discovery Learning Terhadap Kemampuan Berpikir Kritis Muatan Ipa Siswa Kelas Iv Sd Gugus Diponegoro. JRPD (Jurnal Riset Pendidikan Dasar), $3(1)$, 34-40. https://doi.org/10.26618/jrpd.v3i1.3221

2. Azizah, M., Sulianto, J., \& Cintang, N. (2018). Analisis Keterampilan Berpikir Kritis Siswa Sekolah Dasar pada Pembelajaran Matematika Kurikulum 2013. Jurnal Penelitian Pendidikan, 35(1), 61-70. https://doi.org/10.15294/jpp.v35i1.1352 9

3. Fathani, A. H. (2016). Pengembangan Literasi Matematika Sekolah Dalam Perspektif Multiple Intelligences. Edu Sains: Jurnal Pendidikan Sains Dan Matematika, 4(2), 136-150. https://doi.org/10.23971/eds.v4i2.524

4. Ghasya, D. A. V., \& Suryanti. (2014). Pengaruh Model Pembelajaran Arias (Assurance, Relevance, Interest, Kemampuan Berpikir Kreatif Pada Mata Pelajaran Ipa Di Sekolah Dasar. Jpgsd, 2(2), $1-16$. https://jurnalmahasiswa.unesa.ac.id/inde x.php/39/article/view/10596/4184

5. Gunduz, Z. E., \& Unal, I. D. (2016). Effects of Multiple Intelligences Activities on Writing Skill Development in an EFL Context. Universal Journal of Educational Research, 4(7), 1687-1697. https://doi.org/10.13189/ujer.2016.0407 22

6. Hosnan, M. (2014). Pendekatan Saintifik dan Kontekstual dalam Pembelajaran Abad 21. Indonesia: Ghalia Indonesia.

7. Hutomo, B. A., Parmin, \& Miranita, K. (2016). Pengaruh Model Active Learning Berbantuan Media Flash Terhadap Pemahaman Konsep Dan Aktivitas Belajar Siswa SMP Kelas VII Pada Tema Kalor dan Perpindahannya. USEJ: Unnes Science Education 
Journal, $\quad 5(3), \quad$ 1321-1330. https://doi.org/10.15294/usej.v5i3.13156

8. Kristin, F., \& Rahayu, D. (2016). Pengaruh Penerapan Model Pembelajaran Discovery Learning Terhadap Hasil Belajar IPS Pada Siswa Kelas 4 SD. Scholaria: Jurnal Pendidikan Dan Kebudayaan, 6(1), 8492.

https://doi.org/10.24246/j.scholaria.2016 .v6.i1.p84-92

9. Kusumaningtias, D. A., Kurniawan, E. S., \& Ashari. (2014). Pengembangan Handout Berbasis Multiple Intelligence Untuk Meningkatkan Kemampuan Berpikir Kritis Siswa Kelas X SMA Muhammadiyah Wonosobo Tahun Pelajaran 2013/2014. Radiasi: Jurnal Berkala Pendidikan Fisika, 5(2), 80-84. https://doi.org/10.37729/radiasi

10. Lieung, K. W. (2019). Pengaruh Model Discovery Learning terhadap Keterampilan Berpikir Kritis Siswa Sekolah Dasar. Musamus Journal of Primary Education, 1(2), 073-082. https://doi.org/10.35724/musjpe.v1i2.14 65

11. Mareti, J. W., \& Hadiyanti, A. H. D. (2021). Model Problem Based Learning Untuk Meningkatkan Kemampuan Berpikir Kritis dan Hasil Belajar IPA Siswa. Jurnal Elementaria Edukasia, 4(1), 31-41. https://doi.org/10.31949/jee.v6i1.

12. Maula, L. N., \& Arief, A. (2014). Penerapan Pembelajaran Berbasis Kecerdasan Majemuk untuk Meningkatkan Keterampilan Berpikir Kritis Siswa Pada Materi Listrik Dinamis Kelas X MAN Mojokerto. Jurnal Inovasi Pendidikan Fisika (JIPF), 03(03), 46-50. https://ejournal.unesa.ac.id/index.php/in ovasi-pendidikan-fisika/search/search

13. Mujib, M., \& Mardiyah, M. (2017). Kemampuan Berpikir Kritis Matematis Berdasarkan Kecerdasan Multiple Intelligences. Al-Jabar: Jurnal Pendidikan Matematika, 8(2), 187. https://doi.org/10.24042/ajpm.v8i2.2024
14. Pitriani, S., Ningsi, Y., Andrean, S., \& Ningsi, I. (2020). Analisis Pembelajaran Tematik-Integratif Berbasis Multiple Intellegences di Era Revolusi Industri 4.0. El Midad: Jurnal Jurusan PGMI, 12(1), 54-69. https://doi.org/10.20414/elmidad.v12i1. 2333

15. Prihanti, G. S. (2015). Strategi Belajar. Malang: Universitas Muhammadiyah Malang.

https://ummpress.umm.ac.id/katalog/det ail/strategibelajar.html

16. Rosarina, G., Sudin, A., \& Sujana, A. (2016). Penerapan Model Discovery Learning Untuk Meningkatkan Hasil Belajar Siswa Pada Materi Perubahan Wujud Benda. Jurnal Pena Ilmiah, 1(1), 371-380.

https://doi.org/10.17509/jpi.v1i1.3043

17. Septiana, K. G., \& Ikhsan, J. (2017). Pengaruh Penerapan Multiple Intelligences dengan Model PBL Terhadap Pemahaman Konsep dan Kemampuan Berpikir Kreatif. Jurnal Edukasi Matematika Dan Sains, 5(1), 43-52.

https://doi.org/10.25273/jems.v5i1.1785

18. Surtriyanti, E., Panjaitan, R. L., \& Sudin, A. (2017). Pengaruh Metode Pembelajaran Pictorial Riddle Terhadap Keterampilan Berpikir Kritis Siswa SD Pada Materi Pelestarian Lingkungan. Jurnal Pena Ilmiah, 2(1), 331-340. https://doi.org/10.17509/jpi.v2i1.10668

19. Wardani, S., Setiawan, S., \& Supardi, K. I. (2016). Pengaruh Pembelajaran Inkuiri Terbimbing Terhadap Pemahaman Konsep Dan Oral Activities Pada Materi Pokok Reaksi Reduksi Dan Oksidasi. Jurnal Inovasi Pendidikan Kimia, $\quad$ 10(2), 1743-1750. https://doi.org/10.15294/jipk.v10i2.9527

20. Wijayanti, A., Sumarmi, S., \& Amirudin, A. (2016). Perbandingan Model Group Investigation Dengan Problem Based Learning Berbasis Multiple Intelligence Terhadap Kemampuan Memecahkan Masalah Siswa Sma. Jurnal Pendidikan - Teori, 
Erman Suwardi et.al. The effectiveness of application discovery learning model of multiple intelligences-based on science critical thinking skills in grade V elementary school students in Buton Regency.

Penelitian, Dan Pengembangan, 1(5), 948-957.

https://doi.org/10.17977/jp.v1i5.6326

21. Wijayanti, D. A. I., Pudjawan, K., \& Margunayasa I Gd. (2015). Analisis Kemampuan Berpikir Kritis Siswa Kelas V Dalam Pembelajaran IPA di SD No. 1, 2, dan 3 Kaliuntu Gugus $\mathrm{X}$ Kecamatan Buleleng. E-Journal PGSD Universitas Pendidikan Ganesha, 3(1), $1-12$.

https://doi.org/10.23887/jjpgsd.v3i1.574 0

22. Wijayanti, F., \& Widiyatmoko, A. (2015). Pengembangan Lks IPA Berbasis Multiple Intelligences Pada Tema Energi dan Kesehatan untuk Meningkatkan Kemampuan Berpikir Kreatif Siswa. Unnes Science Education Journal, 4(1), 772-779. https://doi.org/10.15294/usej.v4i1.4987
23. Winarti, A., Rahmini, A., \& Almubarak. (2019). Efektivitas Strategi Pemecahan Masalah Kolaboratif Berbasis Kecerdasan Majemuk Untuk Meningkatkan Keterampilan Berpikir Kritis. Jurnal Kependidikan, 3(2), 172186.

https://doi.org/10.21831/jk.v3i2.24714

How to cite this article: Erman Suwardi, Ani Rusilowati, Sri Wardani. The effectiveness of application discovery learning model of multiple intelligences-based on science critical thinking skills in grade $\mathrm{V}$ elementary school students in Buton Regency. International Journal of Research and Review. 2022; 9(2): 261-273. DOI: https:// doi.org/10.52403/ijrr.20220236 